\title{
Gaseous Emissions from the Composting Process: Controlling Parameters and Strategies of Mitigation
}

\author{
Tahseen Sayara ${ }^{1}$ and Antoni Sánchez ${ }^{2, *}$ D \\ 1 Department of Environment and Sustainable Agriculture, Faculty of Agricultural Sciences and Technology, \\ Palestine Technical University-Kadoorie, Tulkarm 7, Palestine; tsayara@yahoo.com \\ 2 Departament d'Enginyeria Química, Biològica i Ambiental, Escola d'Enginyeria, Universitat Autònoma de \\ Barcelona, Bellaterra, 08193 Barcelona, Spain \\ * Correspondence: antoni.sanchez@uab.cat
}

check for updates

Citation: Sayara, T.; Sánchez, A. Gaseous Emissions from the Composting Process: Controlling Parameters and Strategies of Mitigation. Processes 2021, 9, 1844. https://doi.org/10.3390/pr9101844

Academic Editor: Guining Lu

Received: 17 September 2021

Accepted: 14 October 2021

Published: 18 October 202

Publisher's Note: MDPI stays neutral with regard to jurisdictional claims in published maps and institutional affiliations.

Copyright: (c) 2021 by the authors. Licensee MDPI, Basel, Switzerland. This article is an open access article distributed under the terms and conditions of the Creative Commons Attribution (CC BY) license (https:// creativecommons.org/licenses/by/ $4.0 /)$

\begin{abstract}
Organic waste generation, collection, and management have become a crucial problem in modern and developing societies. Among the technologies proposed in a circular economy and sustainability framework, composting has reached a strong relevance in terms of clean technology that permits reintroducing organic matter to the systems. However, composting has also negative environmental impacts, some of them of social concern. This is the case of composting atmospheric emissions, especially in the case of greenhouse gases (GHG) and certain families of volatile organic compounds (VOC). They should be taken into account in any environmental assessment of composting as organic waste management technology. This review presents the relationship between composting operation and composting gaseous emissions, in addition to typical emission values for the main organic wastes that are being composted. Some novel mitigation technologies to reduce gaseous emissions from composting are also presented (use of biochar), although it is evident that a unique solution does not exist, given the variability of exhaust gases from composting.
\end{abstract}

Keywords: organic wastes; composting; gaseous emissions; mitigation strategies

\section{Introduction}

As a result of increasing solid wastes' generation, the implementation of a reliable technology to deal with these wastes is considered as a pillar of sustainable development of any nation [1]. However, the selection of any technology should be compatible with the economic situation within the jurisdiction. Concurrently, the used technology has to satisfy the laws and regulations that fundamentally aim to reduce any environmental and health problems [2]. Among the different technologies used in this field is the composting process, which has been used to deal with solid wastes and mainly for the organic fraction of wastes [3,4]. This process is recognized as an environmentally friendly and cost-effective method, as organic matter is biologically degraded under aerobic conditions [5]. This biodegradation of organic matter contributes to reducing the volume of wastes and producing a stabilized and nutrient-rich final end product, "compost", that could be used in agricultural activities due to its various positive impacts on the physical and chemical properties of the soil, meanwhile reducing utilization of inorganic fertilizers [6-8]. Actually, when the process-controlling parameters are well adjusted, this will lead to different advantages; thereby the process is viewed as a sustainable alternative for landfilling and other treatment options [9]. However, even though composting is a natural biochemical decomposition process, a successful composting operation that produces a valuable end product is normally associated with releasing gaseous emissions including greenhouse gases (GHGs) into the atmosphere (Figure 1). The released GHGs are attributed to energy requirements for composting plants' operation and to the biochemical reactions within the organic waste itself, which produces $\mathrm{CO}_{2}$, methane $\left(\mathrm{CH}_{4}\right)$, and nitrous oxide $\left(\mathrm{N}_{2} \mathrm{O}\right)$ due to the mineralization and degradation of organic matters [10,11]. According to Hao et al. [12], 
the majority of organic carbon is converted to $\mathrm{CO}_{2}$, whereas the methane accounts for less than $6 \%$. Nevertheless, it should be noted that even though $\mathrm{CO}_{2}$ represents the major part of the emissions, it does not add to global warming due to the biogenic origin of carbon. On the contrary, the other emissions resulting from the process such as $\mathrm{CH}_{4}$ and $\mathrm{N}_{2} \mathrm{O}$ have a direct impact on the global warming, while $\mathrm{NH}_{3}$, Sulphur compounds, and most of the volatile organic compounds (VOCs) emissions cause undesirable and other odor nuisances $[9,13,14]$. Indeed, these gases contribute to climate change, global warming, acidification, and eutrophication of ecosystems as a result of $\mathrm{NH}_{3}$ deposition, which also contributes to the formation of particulate matters in the air [9]. As a matter of fact, these GHGs and ammonia $\left(\mathrm{NH}_{3}\right)$ deteriorate the compost quality, besides being a secondary environmental pollution, as mentioned before $[15,16]$.
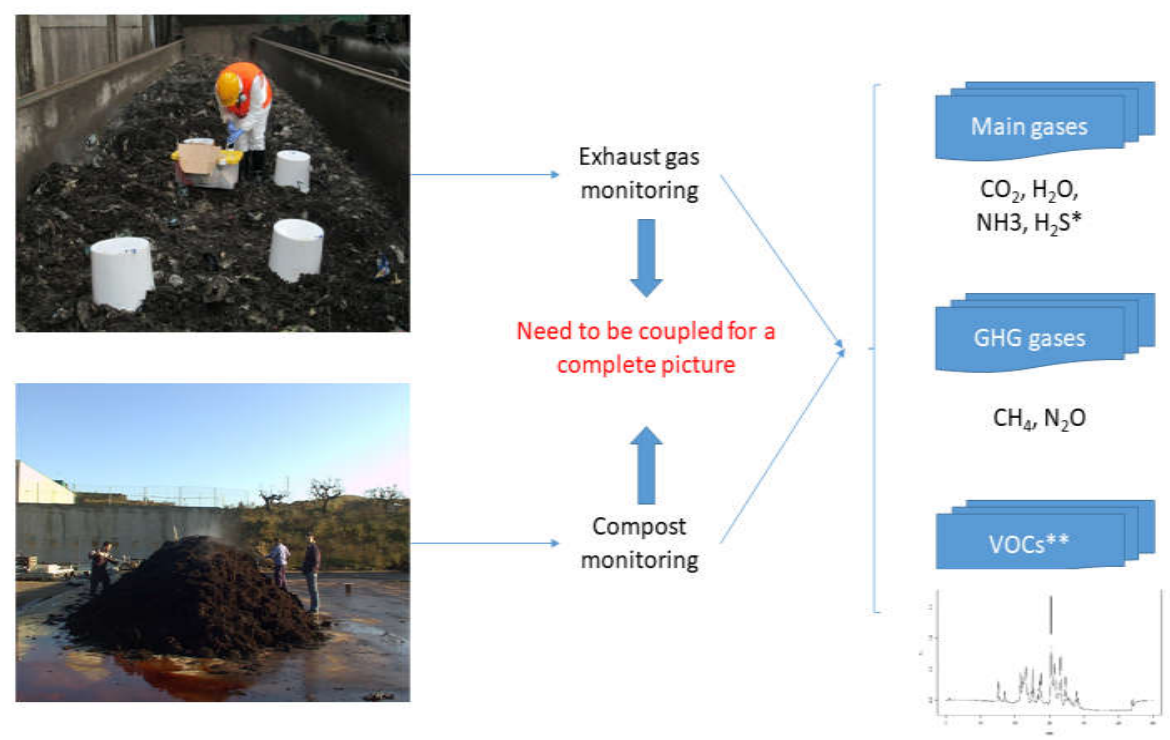

Figure 1. Monitoring exhaust gases from a composting process. ${ }^{*} \mathrm{H}_{2} \mathrm{~S}$ is only significantly observed when anaerobic conditions prevail in the composting process. ${ }^{* *}$ VOCs: Volatile Organic Compounds, a wide group including families such as alcohols, aldehydes, alkanes, aromatic hydrocarbons, carboxylic acids, ketones, nitrogen compounds, phenols, sulphur compounds, and terpenes, among others.

Emissions are formed due to inadequate aerobic conditions of composting [9]. Generally, the creation of anaerobic zones in compost mixtures results in $\mathrm{CH}_{4}$ emissions, whereas nitrogen transformation and loss $\left(\mathrm{NH}_{3}\right.$ and $\left.\mathrm{N}_{2} \mathrm{O}\right)$ are linked to ammonification, nitrification, and denitrification during the composting process [17-19], but still they are less than GHGs' emissions generated from landfilling and waste-to-energy processes [20-22]. During the composting process, various forms of VOCs are formed, where the rates and specific forms of these emissions highly depend on the feedstock materials and composting phases, taking into account that aeration of the composting mixture has a major role in releasing of these compounds $[23,24]$. The rate of gaseous emissions is differing based on the applied composting method, whereas the initial content of the carbon and nitrogen is of great importance in the produced amount of gaseous emissions such that low total carbon (C) and nitrogen (N) content can simultaneously reduce $\mathrm{CH}_{4}, \mathrm{CO}_{2}$, and $\mathrm{N}_{2} \mathrm{O}$ emissions [25]. In this regard, it has been reported that manure composting may account for $46 \%$ and $67 \%$ of the initial $\mathrm{N}$ and $\mathrm{C}$ content of the original manure, respectively [26]. The losses in nitrogen mass are normally in the form of $\mathrm{NH}_{3}$ emissions, whereas nitrous oxide emission, which has 265 times the global warming potential of $\mathrm{CO}_{2}$ [27], accounts for about $0.1-5 \%$ of total $\mathrm{N}$ losses [28-30]. Noteworthy is the amount of these emissions influenced by the composting technology. In this context, silo composting reduced GHGs' losses by 
82.84\% compared with turning composting, which resulted in larger carbon and nitrogen losses [25].

Reducing the impact of the resulting emissions from composting has been investigated and practiced using different approaches. For example, biofilters effectively reduced the $\mathrm{NH}_{3}$ emission with mitigation efficiency (ME) of $97 \%$, whereas adding sawdust or straw reduced $\mathrm{CH}_{4}$ and $\mathrm{N}_{2} \mathrm{O}$ emissions by $66.3 \%$ and $44.0 \%$, respectively, as such types of materials enhance the absorption and microbial assimilation of $\mathrm{NH}_{4}{ }^{+} / \mathrm{NH}_{3}$ [25]. Providing an optimal initial mixture and maintaining aerobic conditions among other practices have been used to mitigated both odors and GHGs [31]. This research presents a comprehensive overview on the gaseous emissions from composting processes. Factors that influence the production of emissions and the mitigation approaches are highlighted also.

\section{Gas Emissions from Composting Process}

As a result of microbial activities and putrefaction, gaseous emissions from organic wastes are produced [10]. These emissions, which include $\mathrm{CO}_{2}, \mathrm{CH}_{4}, \mathrm{~N}_{2} \mathrm{O}$, Sulphur compounds, and many other volatile organic compounds (VOCs), as shown in Table 1, have been detected during the different phases of the waste management $[9,31]$.

Table 1. Volatile organic compounds (VOCs) detected in the composting of different organic wastes.

\begin{tabular}{|c|c|c|c|}
\hline Waste & Main VOC Family & Other VOCs & Reference \\
\hline Poultry litter & Alkanes and alkylated benzenes & Aldehydes, terpenes, and ketones & [32] \\
\hline Chicken manure and biochar & Ketones, phenols, and organic acids & Aliphatic, aromatic, and terpenes & [33] \\
\hline Municipal solid waste & Alkylated benzenes, alcohols, and alkanes & 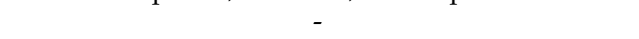 & [14] \\
\hline Wastewater sludge & Terpenes & Furans and esters & [34] \\
\hline Digested wastewater sludge & Terpenes & Alcohols and Ketones & [34] \\
\hline Swine carcass & Sulphur compounds & - & [35] \\
\hline Municipal solid waste & Terpenes & $\begin{array}{l}\text { Alcohols, volatile fatty acids, and } \\
\text { aromatic compounds }\end{array}$ & [36] \\
\hline Livestock and Poultry Manure & $\begin{array}{c}\text { Sulfur compounds, aliphatic } \\
\text { hydrocarbons, aromatic hydrocarbons }\end{array}$ & Chlorinated organic compounds & [37] \\
\hline Municipal solid waste digestate & Terpenes and oxygenated compounds & Sulphur compounds and methanethiol & [38] \\
\hline Green waste & Alcohols & $\begin{array}{l}\text { Alkenes, aliphatic alkanes, aromatic hydrocarbons, } \\
\text { ketones, aldehydes, furans, and esters }\end{array}$ & [39] \\
\hline Sewage sludge & $\begin{array}{l}\text { Isovaleraldehyde, butyric acid, sulphur } \\
\text { compounds, and pinene }\end{array}$ & Indole, skatole, and phenol & {$[40]$} \\
\hline
\end{tabular}

In the composting process, the amount of emitted gases is highly influenced by the type of treated wastes, composting technology, and operational conditions, mainly aeration, which would have a direct impact in reducing the rate of emissions, mainly $\mathrm{N}_{2} \mathrm{O}$ and methane, when it is properly adjusted [9]. According to Goldstein [41], the odors generated from composting plants are attributed to different compounds including terpenes, alcohols, aldehydes, fatty acids, ammonia, and a range of Sulphur compounds. Methane is normally formed during the composting process due to anaerobic condition that could be established in some parts of the composted material such as middle zones of a pile, which suffer from insufficient diffusion of oxygen [12,24]. However, nitrous oxides are produced due to nitrification and denitrification [42], taking into account that other conditions such as temperature, nitrate concentration, and aerobic conditions influence these emissions [43].

For the determination of emissions' rates and their subsequent global impact, emission factor is usually used as a useful tool for VOCs, $\mathrm{NH}_{3}$, or GHGs. The emission factor is usually expressed per ton of treated waste or per amount of obtained compost [44]. For instance, GHGs' emission factor, in terms of $\mathrm{kg} \mathrm{CO}_{2 \mathrm{eq}} \cdot \mathrm{Mg}^{-1}$ dry matter of sewage sludge (DM-SS), was found to be $2.30 \times 10^{2}$. On the other hand, the sewage sludge composting

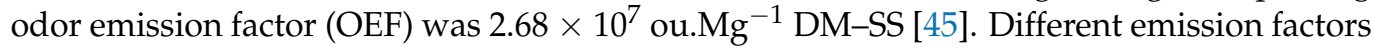
could be found in the literature, depending on the characteristics of the feedstock or the composting technology [46-49]. 
Compared with other treatments or management technologies for solid waste, different studies demonstrated that the composting process has less impact on global warming, as it produces lower amounts of GHGs. In this regard, Lou and Nair [50] showed that composting of municipal solid waste produced about $1.29 \mathrm{t} \mathrm{CO}_{2}$-eq/t-of-waste, which is lower than the amount produced from landfills. Actually, this was concluded and documented by different studies, which emphasized that composting produces lower amounts of emissions ( $\mathrm{g} \mathrm{CO}_{2}$-eq/t-of-waste) compared to landfilling and incineration based on emission factor [21,49-51]. However, when composting and vermicomposting were compared, it was found that the vermicomposting process caused $78.19 \%$ lesser GHGs' emission as compared to the composting process, which released $80.9 \mathrm{~kg} \mathrm{CO}_{2}$-eq/t-of-waste [52].

\section{Factors Affecting the Emissions' Rates}

During the initial stages of the composting process, both nitrogen and sulfur are in the organic form [53]. As the process proceeds forward, the mineralization of the organic nitrogen leads to the formation of ammonia $\left(\mathrm{NH}_{3}\right)$, which could react with hydrogen ions to form ammonium $\left(\mathrm{NH}_{4}{ }^{+}\right)$. The $\mathrm{NH}_{4}{ }^{+}$-to- $\mathrm{NH}_{3}$ equilibrium is highly affected by the dominant conditions within the composting mixture, mainly the $\mathrm{pH}$ value and temperature [54-56]. Thermophilic temperatures and alkaline conditions enhance the loss of nitrogen as ammonia. Additionally, ammonia-oxidizing bacteria or archaea and nitriteoxidizing bacteria convert part of the nitrogen to nitrate through the nitrification process. This nitrate is used by the microbial community, but it would be converted to $\mathrm{N}_{2} \mathrm{O}$ under certain conditions including denitrifications' process, especially under insufficient oxygen levels [54]. Furthermore, the low levels of oxygen lead to the formation of some anaerobic zones within the compositing mixture. These zones play a major role in the sulfur transformation and the production of $\mathrm{H}_{2} \mathrm{~S}$ through the action of Sulfate-reducing bacteria (anaerobic) during the degradation of the organic matter [57]. Additionally, during the formation of $\mathrm{H}_{2} \mathrm{~S}$, other reduced sulfur compounds will also be produced, such as $\mathrm{MeSH}$, $\mathrm{Me}_{2} \mathrm{~S}, \mathrm{Me}_{2} \mathrm{SS}$, and others [54]. The following are some of the main factors that affect the emissions' rates during the composting process.

\subsection{Composting Method}

Composting of solid wastes can be carried out using different technologies [4]. As reported in various studies, the used technology has a direct impact on the rate of gaseous emissions [31]. In this regard, turned and windrow technologies showed higher values of $\mathrm{CH}_{4}, \mathrm{CO}_{2}$, and $\mathrm{N}_{2} \mathrm{O}$ compared with other technologies [25,58-60]. Turning of composted materials increases the chances of releasing trapped gasses within the composting materials and exposing them to the air. The frequent turning helps in re-structuring the materials and improving the porosity; thus, more air could be diffused that supports the microbial activities and promotes the biodegradation of the organic matter, which ultimately increases the amount of $\mathrm{CO}_{2}$ volatilization $[25,61,62]$. Additionally, $\mathrm{N}_{2} \mathrm{O}$ emissions are high in turned piles compared with other technologies. This is attributed to the losses as a result of nitrification near the surface and denitrification by mixing $\mathrm{NO}_{3} / \mathrm{NO}_{2}$ accumulated on the surface into the pile [63-65]. Amlinger et al. [44] suggested that high aeration and effective stripping of $\mathrm{NH}_{3}$ during the early stages of composting can reduce $\mathrm{N}_{2} \mathrm{O}$ formation. Additionally, the enzymatic activity is thought to be affected by turning and increases the $\mathrm{N}_{2} \mathrm{O}$ emissions. Under anoxic conditions, denitrification enzymes are in an equilibrium state; however, when the material is exposed to oxygen as a result of turning, nitrous oxide reductases that can catalyze the transformation of $\mathrm{N}_{2} \mathrm{O}$ to $\mathrm{N}_{2}$ are clearly more severely inhibited by $\mathrm{O}_{2}$ than the other reductases, resulting in a stronger $\mathrm{N}_{2} \mathrm{O}$ emission $[66,67]$. Between turned piles and static systems, lower emissions of $\mathrm{N}_{2} \mathrm{O}$ and $\mathrm{CH}_{4}$ were observed in turned piles, attributed to the difference to the anaerobic zones in the static system [68-70]. In silo composting, the $\mathrm{N}_{2} \mathrm{O}$ and $\mathrm{CH}_{4}$ emissions were lower than other methods. This is because a good aeration system resulted in reducing the chances for the denitrification process. Moreover, more $\mathrm{NH}_{3}$ is emitted from this system, which reduced the substrates 
for $\mathrm{N}_{2} \mathrm{O}$ emissions $[25,59,60]$. Similar observations regarding the aeration effect on the emissions were noticed by Ermolaev et al. [71], such that lower emissions of $\mathrm{CH}_{4}$ and $\mathrm{NO}_{2}$ were observed regardless of the amount of aeration.

\subsection{Average Composting Temperature}

The temperature evolution during the composting process has a direct impact on the rate of gaseous emissions. It is well documented that a positive correlation is normally observed between temperature and emissions' rate, where a higher rate of emissions was recorded with high temperatures and, more specifically, in the thermophilic ranges $\left(45-70{ }^{\circ} \mathrm{C}\right)$ [9]. This could be attributed to the high rate of organic matter decomposition at higher temperature [25,62,72]. In this regard, Fillingham et al. [59] demonstrated that the highest $\mathrm{NH}_{3}$ emissions were recorded in silo composting (111.07 $\mathrm{g}\left[\mathrm{NH}_{3}-\mathrm{N}\right] \mathrm{kg}^{-1}$ [TN]) compared to windrow composting, and the difference was attributed to high temperatures, which were about $65^{\circ} \mathrm{C}$ in silo composting. These conditions enhance the equilibrium between ammonium and $\mathrm{NH}_{3}$ towards gaseous $\mathrm{NH}_{3}$, whereas low temperature inhibits microbial ammonization, thus reducing $\mathrm{NH}_{3}$ emissions [25,63]. Similarly, elevated temperatures result in increasing $\mathrm{CH}_{4}$ emissions. This could be explained by the high rate of microbial activities that result in increasing the temperatures, and these conditions are associated with high oxygen consumption, which ultimately leads to forming anaerobic conditions and the formation of $\mathrm{CH}_{4}[45,72-74]$. The same trend was also observed regarding $\mathrm{CO}_{2}$ and $\mathrm{N}_{2} \mathrm{O}$ emissions that exhibit an increase with increasing temperature [63,75]. In this context, the maximum concentrations measured during sewage sludge composting were 2600 ppmv of $\mathrm{NH}_{3}, 66$ ppmv of $\mathrm{H}_{2} \mathrm{~S}$, and 1650 ppmv of tVOCs, which were observed during the peak of maximum temperature of the reactor [76]. Accordingly, controlling this parameter would help in controlling the emissions' rates [9].

\subsection{Initial Moisture Content}

Providing an optimum moisture content is crucial for the composting process performance, as it will promote the microbial activities [4]. However, increasing moisture content above the recommended values (40-60\%) would result in creating anaerobic zones within the composted materials [25]. This was clear regarding $\mathrm{CH}_{4}$ emissions that were positively correlated to the moisture content of the compost [28,77], meanwhile a negative correlation with moisture content was recorded regarding the $\mathrm{CO}_{2}$ emissions [25]. However, for $\mathrm{N}_{2} \mathrm{O}$ emissions, the correlation with moisture content is not well established. For instance, Hwang and Hanaki [78] demonstrated that $\mathrm{N}_{2} \mathrm{O}$ emissions decreased when the material became very moist because of the inhibition of $\mathrm{N}_{2} \mathrm{O}$ nitrification, but Yan et al. [79] showed that the $\mathrm{N}_{2} \mathrm{O}$ would increase with water content as aerobic and anaerobic zones would simultaneously exist and also the nitrification and denitrification might be promoted concurrently and $\mathrm{N}_{2} \mathrm{O}$ emission flux could become relatively high.

\subsection{Initial Total Carbon (TC) and Initial Total Nitrogen (TN) Content}

Carbon and nitrogen are essential for the microbial activities during the composting process. Providing an adequate ratio of carbon and nitrogen (normally indicated as $\mathrm{C} / \mathrm{N}$ ratio, with recommended values between 25:1 to 30:1) is considered as one of the controlling parameters in this process [25,31]. Importantly, these elements also have an impact on the rate of emissions resulting from the process. When the microbial communities biodegrade the organic matter under aerobic condition, most of the carbon is lost as $\mathrm{CO}_{2}$, such that a linear relation between carbon content and $\mathrm{CO}_{2}$ emissions would be observed during the process [76]. Furthermore, initial carbon content was found to have a positive correlation with $\mathrm{CH}_{4}$ emissions [80], considering the nitrogen content, which is a primary source for methanogenic bacteria $[11,81]$. Similarly, the rate of $\mathrm{N}_{2} \mathrm{O}$ emissions is positively correlated with nitrogen content, as both nitrification and denitrification are enhanced by a high content of nitrogen $[65,82]$. Usually, composting feedstocks with low $\mathrm{C} / \mathrm{N}$ ratios and 
high moisture contents provides favorable conditions of producing more greenhouse gas emissions [31]. Ammonia emissions are also affected by the $\mathrm{C} / \mathrm{N}$ ratio $[31,73,83,84]$.

\subsection{Aeration Rate}

As an aerobic process, supplying a sufficient amount of oxygen is recognized as an important parameter for maintaining the microbial activity and reducing the gas emission during the composting process [85]. Sufficient aeration through forced aeration or mechanical turning would guarantee the non-formation of anaerobic zones within the composting mixture, thereby reducing odor problems $[9,86]$. Importantly, and per statistical analysis, it absolutely was clear that aeration rate was the foremost important factor that could significantly affect the $\mathrm{NH}_{3}, \mathrm{CH}_{4}$, and $\mathrm{N}_{2} \mathrm{O}$ emissions [5,87]. Rosenfeld et al. [88] indicated that aeration reduced the concentrations of $\mathrm{NH}_{3}, \mathrm{CH}_{2} \mathrm{O}_{2}$, and $\mathrm{CH}_{3} \mathrm{COOH}$ by $72 \%, 57 \%$, and $11 \%$, respectively, compared to the windrow. Additionally, Quiros et al. [89] reported a reduction in emissions' rates by five times when frequent turning was employed compared to non-turned treatments. However, it should be taken into account that an adequate aeration rate has to be applied that would maintain the biological activity and reduce the emissions' rates at the same time [5,90-92]. Applying higher aeration rates would reduce some emissions such as $\mathrm{CH}_{4}$, but others such as $\mathrm{NH}_{3}$ and $\mathrm{N}_{2} \mathrm{O}$ would be promoted. Additionally, higher aeration rates might render temperature evolution, thus decelerating the degradation of the organic matter as a consequence [5]. Results obtained by Chowdhury et al. [90] showed that low aeration rates were more practical in reducing GHGs' emissions. The same observation was reported by Zhang et al. [93] during composting of kitchen waste, where aeration rates of $0.1,0.2$, and $0.3 \mathrm{~L}(\mathrm{~kg} \mathrm{DM} \mathrm{min})^{-1}$ were studied and it was found that the lower aeration was more significant than the other two treatments. Additionally, it was indicated that intermittent aeration was better than continuous aeration in mitigating $\mathrm{CO}_{2}$ emissions [9]. Nevertheless, Ermolaev et al. [71] indicated that aeration reduced the emissions of $\mathrm{CH}_{4}$ and $\mathrm{NO}_{2}$ regardless of the rate of aeration. Turning of the composted mixtures has a positive impact on reducing the rate of emissions also. This is because turning gives the chance for air exchange and releasing of different gases, as indicated in different studies [11,17]. The efficiency of aeration and turning in reducing emissions' rates was evaluated by Friedrich and Trois [10] during composting of garden waste. The study revealed that turning resulted in $8.14 \%$ higher GHGs than an aerated treatment. These findings prove that aeration is better than other treatments in reducing GHGs' emissions [94,95]. Another important element for maintaining the aerobic conditions is providing an optimal ratio of a bulking agent that provides proper structure and porosity for the composting mixture [31], meanwhile maintaining the heat and biological activity $[96,97]$. This will be deeply discussed in the following section.

\section{6. $p H$ Value}

An optimum $\mathrm{pH}$ value between 6 and 8 (ideally 7) is recommended for microbial population during successful composting process. However, this parameter fluctuates, especially during the first stages of the process as organic acids are released due to organic matter degradation and, thus, the $\mathrm{pH}$ decreases. After that, a gradual increase in alkalinity occurs as a result of the phenolic and carboxyl groups' decomposition [4]. The increase in the $\mathrm{pH}$ level promotes ammonia release, by influencing the $\mathrm{NH}_{4}{ }^{+}$to $\mathrm{NH}_{3}$ equilibrium in spite of its directs influence on biological activity, as indicated [54,55]. However, these conditions are considered suitable for decreasing other emissions such as $\mathrm{H}_{2} \mathrm{~S}$, which normally increases under low $\mathrm{pH}$ values [56]. These behaviors were documented by $\mathrm{Gu}$ et al. [98], where reducing the $\mathrm{pH}$ of compost resulted in reducing the cumulative $\mathrm{NH}_{3}$ emissions and $\mathrm{TN}$ losses by $47.80 \%$ and $44.23 \%$, while an increase in the emissions of volatile sulfur compounds and total sulfur losses was observed. More information and details about the effect of $\mathrm{pH}$ adjustment to mitigate the emission rates are provided in Section 4.4. 


\section{Mitigation Strategies}

\subsection{Providing Adequate Bulking Agent}

The addition of some materials to organic wastes has proven its efficiency in improving air convection within the composting mixture, thereby reducing the amount of gases' emissions such as $\mathrm{CH}_{4}$ and $\mathrm{N}_{2} \mathrm{O}$ from composting, since most of the degraded carbon would be released as $\mathrm{CO}_{2}[11,28,90]$. For instance, sawdust and straw for dairy manure composting resulted in an effective mitigation for $\mathrm{CH}_{4}$ and $\mathrm{NH}_{3}$ with $\mathrm{ME}$ values of $66.3 \%$ and $44.0 \%$, but they may increase $\mathrm{CO}_{2}$ emission [12,99]. Additionally, Li et al. [94] demonstrated that ammonia emission may well be mitigated by adding a mix of sucrose and straw powder at the start stage of a composting process [95]. Indeed, these materials facilitate the absorption and microbial assimilation of ammonium, which decreases $\mathrm{NH}_{3}$ emissions $[9,25,95]$.

\subsection{Introducing Microorganism for Promoting Nitrification Process and Reducing $\mathrm{NH}_{3}$ Emissions}

This approach stands on the mineralization of organic nitrogen into ammonium nitrogen, which could be transformed into nitrate by nitrification and eventually to $\mathrm{N}_{2}$ by denitrification, or the ammonium could even be also a fixed microbial protein under the action of fungi $[25,90,100-103]$. It was found that the introduction of mature compost rich in nitrifying microorganism to food wastes' composting was able to reduce $\mathrm{NH}_{3}$ volatilization by $36 \%$ [104]. Nevertheless, and despite the capability of this approach in reducing $\mathrm{NH}_{3}$ emission, regulating the denitrification process to reduce $\mathrm{N}_{2}$ and $\mathrm{N}_{2} \mathrm{O}$ still represents a challenge for its successful application $[5,103]$. Additionally, the introduction of some exogenous microbial communities including CC-E (a complex bacterial community in which Alcaligenes faecalis is the main advantageous strain) and EM (Effective Microorganisms, a kind of commercial microbiological agent) for dairy manure composting reduced the potential for $\mathrm{NH}_{3}$ emissions, with ME of 9.15\% [104,105].

\subsection{Vermicomposting}

This composting approach demonstrated promising results in reducing the amounts of gaseous emissions including nitrous oxide, $\mathrm{CH}_{4}, \mathrm{NH}_{3}$, and others $[95,106]$. The decrease in emissions' rates is attributed to the reduction of anaerobic denitrification, due to the burrowing action of the earthworms [107]. Furthermore, the large specific surface area and loose texture in vermicomposting contribute to creating a strong adsorption capacity and, at last, reducing production of different emissions, among them the $\mathrm{NH}_{3}$, where vermicomposting was able to mitigate $\mathrm{NH}_{3}$ emission with a ME median value of $33.5 \%[15,25,108]$. The loss of texture improves the aerobic conditions and, therefore, the biodegradation of the organic matter as a consequence. In this regard, it was noticed that $\mathrm{CO}_{2}$ emissions were increased, whereas a decrease in ammonia emissions and nitrous oxide was noticed as well as a sink of methane in treatments with earthworms $[109,110]$. Similar results were obtained by Chan et al. [108] and Velasco-Velasco et al. [111]. Combining pre-composting and vermicomposting with additions of reed straw and zeolite resulted also in a significant reduction of ammonia, nitrous oxide, and methane during composting of duck manure $[95,111]$.

\subsection{Using Different Additives}

The addition of phosphogypsum results in decreasing the $\mathrm{pH}$ of the composting mixture. The high sulphide concentrations and acidic conditions due to the use of phosphogypsum could inhibit methanogenesis and the action of $\mathrm{N}_{2} \mathrm{O}$ reductase, thus reducing $\mathrm{CH}_{4}$ and $\mathrm{N}_{2} \mathrm{O}$ emissions $[12,25,112,113]$. Additionally, adjustment of $\mathrm{pH}$ has been practiced to reduce the emissions of $\mathrm{NH}_{3}$. About $55.7 \%$ of $\mathrm{NH}_{3}$ emissions was decreased due to the reduction in volatilization when phosphogypsum was applied [114]. Additionally, the addition of both $\mathrm{K}_{2} \mathrm{HPO}_{4} / \mathrm{MgSO}_{4}$ and $\mathrm{KH}_{2} \mathrm{PO}_{4} / \mathrm{MgSO}_{4}$ as a $\mathrm{pH}$ buffer agent's additive contributed to reducing $\mathrm{NH}_{3}$ emissions [100]. However, health risks due to high hydrogen sulphide concentrations have to be considered when this mitigation method is 
to be used [25,115]. Manure acidification significantly (up to 93\%) decreased the emissions during storage and composting processes [116,117]. Excessive acidification $(\mathrm{pH}=5)$, on the other hand, increased $\mathrm{N}_{2} \mathrm{O}$ emissions $(18.6 \%)$ during composting. When manure was acidified to $\mathrm{pH}$ of $6, \mathrm{~N}_{2} \mathrm{O}(17.6 \%)$ and $\mathrm{CH}_{4}(20 \%)$ emissions, as well as GHG emissions, represented as global warming potential (GWP) (9.6\%) were reduced during composting [118]. The addition of calcium magnesium phosphate fertilizer $(\mathrm{CaMgP})$ also demonstrated its effectiveness in reducing emissions' rates during the composting process [119]. In this regard, Zhang et al. [93] reported that CaMgP could reduce $\mathrm{H}_{2} \mathrm{~S}$ emissions by $65 \%$. Similar results were obtained when the effect of calcium magnesium phosphate fertilizer $(\mathrm{CaMgP})$, biochar, and spent mushroom substrate (SMS) additives was investigated on compost maturity and gaseous emissions during pig manure composting. Ammonia $\left(\mathrm{NH}_{3}\right)$, hydrogen sulfide $\left(\mathrm{H}_{2} \mathrm{~S}\right)$, dimethyl sulfide $\left(\mathrm{Me}_{2} \mathrm{~S}\right)$, and dimethyl disulfide $\left(\mathrm{Me}_{2} \mathrm{SS}\right)$ emissions could all be reduced using the three additives. However, when it came to reducing $\mathrm{NH}_{3}$ emissions, the effect of adding CaMgP was the most noticeable (42.90\%). CaMgP to $\mathrm{H}_{2} \mathrm{~S}$ emission reduction was similar to SMS, which was $34.91 \%$ and $32.88 \%$, respectively. The three additives had obvious emission reduction effects on $\mathrm{Me}_{2} \mathrm{~S}$ and $\mathrm{Me}_{2} \mathrm{SS}$, all of which were greater than $50 \%$. Adding SMS, on the other hand, reduced $\mathrm{N}_{2} \mathrm{O}$ emissions by $37.08 \%$ [120].

Struvite could also be used to reduce emissions as struvite crystallization enhances nitrogen (ammonium) conservation during composting, which thereby reduces $\mathrm{NH}_{3}$ emissions $[47,121]$. However, this approach increases the salinity of the produced compost $[5,94]$, but this limitation could be mitigated by using other additives like lime or zeolite [18,122]. In this regard, the addition of $10 \%$ of zeolite decreased the salinity to $2.8 \mathrm{mS} \mathrm{cm}^{-1}$ and improved compost maturity; meanwhile, about $18 \%$ of $\mathrm{NH}_{3}$ loss was achieved [122].

\subsection{Compressing and Covering}

This approach depends on reducing the amount of $\mathrm{O}_{2}$ supplied to the mixture, thus lowering the microbial activity and ammonization, which reduce $\mathrm{CO}_{2}$ and $\mathrm{NH}_{3}$ emissions during the composting process $[101,123]$. Additionally, covering reduces gaseous diffusion into the air and enhances the absorption of some gas emissions. Analysis revealed that this approach could reach a mitigation efficiency of $10.1 \%$ for $\mathrm{CO}_{2}$ and $24.3 \%$ for $\mathrm{NH}_{3}$ emission. However, it should be noted that this approach would increase the anaerobic conditions that ultimately promote the production of $\mathrm{CH}_{4}[15,25,107,109]$. Different materials are used as a cover for composting mixture. These materials include sawdust, plastic, soil, paper waste, woodchip, wheat straw, peat, and zeolite, among others. Sawdust or straw has a good performance in absorption of $\mathrm{CO}_{2}$ and $\mathrm{NH}_{3}$, whereas plastic cover renders the gas exchange, which reduces the dissipation of the emissions $[15,25,109,124,125]$. Different forms of zeolite were used as a cover or even mixed with the composting mixture and proved higher efficiency in reducing emission compared to other cover materials with almost no effect on the microbial activity $[5,93,104,126,127]$. This material contributes to increasing the $\mathrm{pH}$ and initial $\mathrm{NH}_{3} / \mathrm{NH}_{4}{ }^{+}$concentration, which reduces $\mathrm{NH}_{3}$ losses such that a reduction of $44-60 \%$ of the $\mathrm{NH}_{3}$ was obtained during poultry manure composting [128]. Similar results were observed by Madrini et al. [126] in composting of leftover food. It should be noted that the type of zeolite and its percentage within the mixture affects the reduction rate of emissions [5,127].

\subsection{Biofiltration}

Biofilters, which depend on adsorption or biodegradation of pollutants, have proven their relative efficiency in reducing emissions from the composting process, especially with $\mathrm{NH}_{3}$, where almost about $90 \%$ of this gas was reduced $[25,129]$. Actually, ammonia emissions in a composting process of organic fraction of municipal solid wastes varied between 18 to $150 \mathrm{~g} \mathrm{NH}_{3} \cdot \mathrm{Mg}^{-1}$ waste [130], while ammonia concentrations up to $700 \mathrm{mg} \mathrm{NH}_{3} \cdot \mathrm{m}^{-3}$ have been reported in exhaust gases from sludge composting [4]. As documented by Pagans et al. [131], the biofilter achieved a global ammonia removal efficiency of $95.9 \%$ at a loading rate range of $846-67100 \mathrm{mg} \mathrm{NH} \mathrm{NH}_{3} \cdot 3$ biofilter $\cdot \mathrm{h}^{-1}$, whereas higher removal rates were 
seen when the waste gas had high $\mathrm{NH}_{3}$ concentrations (more than $2000 \mathrm{mg} \mathrm{NH} \mathrm{N}_{3} \cdot \mathrm{m}^{-3}$ ). However, this approach is more feasible compared to other technologies when it is used in closed systems with collection equipment [15]. Furthermore, the complexity and uncertainty measures in operating the system, as well as understanding the biodegradation process, are critical for optimal performance. [9]. Concerning $\mathrm{CH}_{4}, \mathrm{CO}_{2}$, and $\mathrm{N}_{2} \mathrm{O}$ emissions, the literature is lacking information about the efficiency of biofilter for treatment of these emissions [25].

\subsection{Addition of Biochar}

Biochar as an additive has been used in different research to mitigate the emissions resulting from composting processes $[94,100,120,132,133]$. This additive has been used as a sole material or mixed with other additives [134]. Noteworthy, under almost all studied conditions, promising results were obtained, despite the lack of clarity regarding its mechanism on promoting nitrogen assimilation and nitrification $[5,90,102,135]$. The change in nitrogen functional groups on the biochar surface was evidence for adsorption and microbial transformation of $\mathrm{NH}_{3} / \mathrm{NH}_{4}{ }^{+}$[136]. As indicated in several works, the biochar promoted microbial activity during the composting process, as it increases the nitrogen source and decreases toxicity of free $\mathrm{NH}_{3}$ on the microbial activity [137]; hence, a high respiration rate as well as a fast decomposition of organic matter were recorded [135,137,138]. Additionally, this was associated with an increase in the temperature and $\mathrm{NO}_{3}$ concentration along with a decrease in the $\mathrm{pH}$ and $\mathrm{NH}_{4}{ }^{+}$concentrations [131,133]. Emissions of $\mathrm{NH}_{3}$ and nitrogen losses were reduced by $64 \%$ and $52 \%$, respectively, when biochar was mixed with poultry litters [101]. Similar results were observed when cornstalk biochar was used where cumulative $\mathrm{NH}_{3}$ emissions were reduced by $24.8 \%$ [139]. The presence of the biochar boosted the activity of nitrifiers due to its high sorption capacity for gases and the high cation exchange capacity. According to Zhou et al. [140], adding modified biochar could significantly reduce $\mathrm{NH}_{3}$ emissions by increasing the number of ammonia-oxidizing bacteria (AOB), inhibiting urease activity, and decreasing the abundance of nitrogen functional genes such as narG and nirS, facilitating the conversion of $\mathrm{NH}^{+}{ }_{4}-\mathrm{N}_{\text {into }} \mathrm{NO}^{-}{ }_{3}-\mathrm{N}$ and decreasing nitrogen loss. These conditions were responsible for promoting $\mathrm{N}_{2} \mathrm{O}$ reduction up to $59.8 \%$ [141]. The effects of bamboo charcoal (BC) and bamboo vinegar (BV) on lowering $\mathrm{NH}_{3}$ and $\mathrm{N}_{2} \mathrm{O}$ emissions during aerobic composting (Wheat straw and pig manure) revealed that both $\mathrm{BC}$ and $\mathrm{BV}$ enhanced nitrogen conversion and compost quality, with the combination $\mathrm{BC}+\mathrm{BV}$ treatment achieving the greatest results. The $\mathrm{BC}, \mathrm{BV}$, and $\mathrm{BC}+\mathrm{BV}$ treatments decreased $\mathrm{NH}_{3}$ emissions by $14.35 \%, 17.90 \%$, and $29.83 \%$, respectively, and the $\mathrm{N}_{2} \mathrm{O}$ emissions by $44.83 \%, 55.96 \%$, and $74.53 \%$. BC and $\mathrm{BV}$ reduced the $\mathrm{NH}_{3}$ and $\mathrm{N}_{2} \mathrm{O}$ emissions during composting [142]. Similarly, Biochar (BC) and bean dregs' (BD) effects on nitrifiers and denitrifiers, as well as contributions to $\mathrm{NH}_{3}$ and $\mathrm{N}_{2} \mathrm{O}$ emissions, were investigated by Yang et al. [143]. When comparing the $\mathrm{BD}+\mathrm{BC}$ treatment to the $\mathrm{BD}$ treatment, the highest value of $\mathrm{NH}_{3}$ and $\mathrm{N}_{2} \mathrm{O}$ emission was reduced by $32.92 \%$ and $46.61 \%$, respectively. The number and structure of nitrogen functional genes were shown to be closely related to the synthesis of $\mathrm{NH}_{3}$ and $\mathrm{N}_{2} \mathrm{O}$ in the study. In this case, it was discovered that $\mathrm{BD}+\mathrm{BC}$ enhanced the abundance of the $\mathrm{AOB}$ amoA gene, resulting in a reduction in $\mathrm{NH}_{3}$ emission. The presence of nirS was more closely linked to the presence of $\mathrm{N}_{2} \mathrm{O}$. When compared to the $\mathrm{BD}$ treatment, the abundance of nirS in the $\mathrm{BD}+\mathrm{BC}$ treatment was reduced by $18.93 \%$, lowering $\mathrm{N}_{2} \mathrm{O}$ emissions after composting. Furthermore, the nosZ-type gene was the most functional denitrification bacterial community to influence $\mathrm{N}_{2} \mathrm{O}$ emissions. [143]. Noteworthy, when biochar is to be used, it is important to keep in mind that its characteristics have a major role on its efficiency.

\section{Conclusions}

Composting is a favorable technology to treat organic waste, but gaseous emissions are an issue of major concern for its development. Among them, GHG emissions are an important problem as they are responsible for the global warming effect. Carbon 
dioxide is not often considered, as it is considered biogenic. However, methane and nitrous oxide, related to anaerobic and anoxic conditions, must be accounted for when analyzing any composting process. Another important point is the release in the form of gaseous emissions of a vast family of compounds such as VOCs. These gases can be harmful, possess negative impacts, and, especially, are responsible for unpleasant odors. The origin of these gases is double (they can come from the substrate or be biologically or even chemically formed during the process) and they need the development of mitigation strategies based on relatively consolidated technologies (such as biofiltration) or new approaches, such as the use of materials as biochar. However, there is still a lack of reliable and full-scale data from composting emissions to have consistent mitigation strategies.

Author Contributions: Writing—original draft preparation, T.S.; writing—review and editing, A.S. All authors have read and agreed to the published version of the manuscript.

Funding: This research received no external funding.

Acknowledgments: Sayara would like to thank the Palestine Technical University for the administrative support.

Conflicts of Interest: The authors declare no conflict of interest.

\section{References}

1. Iqbal, A.; Liu, X.; Chen, G. Municipal solid waste: Review of best practices in application of life cycle assessment and sus-tainable management techniques. Sci. Total Environ. 2020, 729, 138622. [CrossRef]

2. Kaza, S.; Yao, L.; Bhada-Tata, P.; Van Woerden, F. What a Waste 2.0: A Global Snapshot of Solid Waste Management to 2050; Urban Development Series; World Bank Publications: Washington, DC, USA, 2018. [CrossRef]

3. Bogner, J.; Pipatti, R.; Hashimoto, R.; Diaz, C.; Mareckova, K.; Diaz, L.; Kjeldsen, P.S.; Faaij, A.; Gao, Q.; Zhang, T.; et al. Mitigation of global GHG emissions from waste: Conclusions and strategies from the Intergovernmental Panel on Climate Change (IPCC) Fourth Assessment Report. Working Group III (Mitigation). Waste Manag. Res. 2008, 26, 11-13. [CrossRef] [PubMed]

4. Haug, R. The Practical Handbook of Compost Engineering; Lewis Publishers: Boca Raton, FL, USA, 1993. [CrossRef]

5. Wang, S.; Zeng, Y. Ammonia emission mitigation in food waste composting: A review. Bioresour. Technol. 2018, $248,13-19$. [CrossRef] [PubMed]

6. Hodge, K.L.; Levis, J.W.; Decarolis, J.F.; Barlaz, M.A. Systematic Evaluation of Industrial, Commercial, and Institutional Food Waste Management Strategies in the United States. Environ. Sci. Technol. 2016, 50, 8444-8452. [CrossRef] [PubMed]

7. Sayara, T.; Basheer-Salimia, R.; Hawamde, F.; Sanchez, A. Recycling of Organic Wastes through Composting: Process Per-formance and Compost Application in Agriculture. Agronomy 2020, 10, 1838. [CrossRef]

8. Varma, V.S.; Kalamdhad, A.S. Stability and microbial community analysis during rotary drum composting of vegetable waste. Int. J. Recycl. Org. Waste Agric. 2014, 3, 52. [CrossRef]

9. Dhamodharan, K.; Varma, V.S.; Veluchamy, C.; Pugazhendhi, A.; Rajendran, K. Emission of volatile organic compounds from composting: A review on assessment, treatment and perspectives. Sci. Total. Environ. 2019, 695, 133725. [CrossRef]

10. Friedrich, E.; Trois, C. GHG emission factors developed for the recycling and composting of municipal waste in South African municipalities. Waste Manag. 2013, 33, 2520-2531. [CrossRef]

11. Luo, W.; Yuan, J.; Luo, Y.M.; Li, G.X.; Nghiem, L.; Price, W.E. Effects of mixing and covering with mature compost on gaseous emissions during composting. Chemosphere 2014, 117, 14-19. [CrossRef]

12. Hao, X.; Chang, C.; Larney, F.J. Carbon, nitrogen balances and greenhouse gas emission during cattle feedlot manure composting. J. Environ. Qual. 2004, 33, 37-44. [CrossRef]

13. Colón, J.; Cadena, E.; Pognani, M.; Barrena, R.; Sánchez, A.; Font, X.; Artola, A. Determination of the energy and environ-mental burdens associated with the biological treatment of source-separated municipal solid wastes. Energy Environ. Sci. 2012, 5, 5731-5741. [CrossRef]

14. Komilis, D.P.; Ham, R.K.; Park, J.K. Emission of volatile organic compounds during composting of municipal solid wastes. Water Res. 2004, 38, 1707-1714. [CrossRef] [PubMed]

15. Wang, Y.; Li, X.; Yang, J.; Tian, Z.; Sun, Q.; Xue, W.; Dong, H. Mitigating Greenhouse Gas and Ammonia Emissions from Beef Cattle Feedlot Production: A System Meta-Analysis. Environ. Sci. Technol. 2018, 52, 11232-11242. [CrossRef]

16. Zhu, L.; Yang, H.; Zhao, Y.; Kang, K.; Liu, Y.; He, P.; Wu, Z.; Wei, Z. Biochar combined with montmorillonite amendments increase bioavailable organic nitrogen and reduce nitrogen loss during composting. Bioresour. Technol. 2019, 294, 122224. [CrossRef] [PubMed]

17. Jiang, T.; Li, G.; Tang, Q.; Ma, X.; Wang, G.; Schuchardt, F. Effects of aeration method and aeration rate on greenhouse gas emissions during composting of pig feces in pilot scale. J. Environ. Sci. 2015, 31, 124-132. [CrossRef]

18. Wang, X.; Selvam, A.; Wong, J.W. Influence of lime on struvite formation and nitrogen conservation during food waste composting. Bioresour. Technol. 2016, 217, 227-232. [CrossRef] [PubMed] 
19. Yang, F.; Li, G.; Shi, H.; Wang, Y. Effects of phosphogypsum and superphosphate on compost maturity and gaseous emis-sions during kitchen waste composting. Waste Manag. 2015, 36, 70-76. [CrossRef]

20. Friedrich, E.; Trois, C. Quantification of greenhouse gas emissions from waste management processes for municipalities-A comparative review focusing on Africa. Waste Manag. 2011, 31, 1585-1596. [CrossRef] [PubMed]

21. Saer, A.; Lansing, S.; Davitt, N.H.; Graves, R.E. Life cycle assessment of a food waste composting system: Environmental impact hotspots. J. Clean. Prod. 2013, 52, 234-244. [CrossRef]

22. Wang, K.; Nakakubo, T. Comparative assessment of waste disposal systems and technologies with regard to greenhouse gas emissions: A case study of municipal solid waste treatment options in China. J. Clean. Prod. 2020, 260, 120827. [CrossRef]

23. Delgado-Rodríguez, M.; Ruiz-Montoya, M.; Giráldez, I.; Cabeza, I.O.; Lopez, R.; Diaz, M.J. Effect of control parameters on emitted volatile compounds in municipal solid waste and pine trimmings composting. J. Environ. Sci. Heal. Part. A 2010, 45, 855-862. [CrossRef]

24. Font, X.; Artola, A.; Sánchez, A. Detection, Composition and Treatment of Volatile Organic Compounds from Waste Treatment Plants. Sensors 2011, 11, 4043-4059. [CrossRef]

25. Ba, S.; Qu, Q.; Zhang, K.; Groot, J.C.J. Meta-analysis of greenhouse gas and ammonia emissions from dairy manure com-posting. Biosyst. Eng. 2020, 193, 126-137. [CrossRef]

26. Shah, G.M.; Groot, J.C.J.; Oenema, O.; Lantinga, E.A. Covered storage reduces losses and improves crop utilisation of nitrogen from solid cattle manure. Nutr. Cycl. Agroecosyst. 2012, 94, 299-312. [CrossRef]

27. IPCC. Climate change 2013: The physical science Basis. In Contribution of Working Group I to the Fifth Assessment Report of the Intergovernmental Panel on Climate Change; Intergovernmental Panel on Climate Change (IPCC): Geneva, Switzerland, 2013.

28. Maeda, K.; Hanajima, D.; Morioka, R.; Toyoda, S.; Yoshida, N.; Osada, T. Mitigation of greenhouse gas emission from the cattle manure composting process by use of a bulking agent. Soil Sci. Plant. Nutr. 2013, 59, 96-106. [CrossRef]

29. Mulbry, W.; Ahn, H. Greenhouse gas emissions during composting of dairy manure: Influence of the timing of pile mixing on total emissions. Biosyst. Eng. 2014, 126, 117-122. [CrossRef]

30. Sommer, S.G. Effect of composting on nutrient loss and nitrogen availability of cattle deep litter. Eur. J. Agron. 2001, 14, 123-133. [CrossRef]

31. Sánchez, A.; Artola, A.; Font, X.; Gea, T.; Barrena, R.; Gabriel, D.; Sanchez-Monedero, M.; Roig, A.; Cayuela, M.L.; Mondini, C. Greenhouse gas emissions from organic waste composting. Environ. Chem. Lett. 2015, 13, 223-238. [CrossRef]

32. Turan, N.G.; Akdemir, A.; Ergun, O.N. Emission of Volatile Organic Compounds during Composting of Poultry Litter. Water, Air, Soil Pollut. 2007, 184, 177-182. [CrossRef]

33. Sánchez-Monedero, M.A.; Sánchez-García, M.; Alburquerque, J.A.; Cayuela, M.L. Biochar reduces volatile organic com-pounds generated during chicken manure composting. Bioresour Technol. 2019, 288, 121584. [CrossRef] [PubMed]

34. Maulini-Duran, C.; Artola, A.; Font, X.; Sánchez, A. A systematic study of the gaseous emissions from biosolids composting: Raw sludge versus anaerobically digested sludge. Bioresour. Technol. 2013, 147, 43-51. [CrossRef] [PubMed]

35. Akdeniz, N.; Koziel, J.A.; Ahn, H.K.; Glanville, T.D.; Crawford, B.P.; Raman, D.R. Laboratory scale evaluation of volatile organic compound emissions as indication of swine carcass degradation inside biosecure composting units. Bioresour. Technol. 2010, 101, 71-78. [CrossRef] [PubMed]

36. Sánchez-Monedero, M.A.; Fernández-Hernández, A.; Higashikawa, F.S.; Cayuela, M.L. Relationships between emitted volatile organic compounds and their concentration in the pile during municipal solid waste composting. Waste Manag. 2018, 79, 179-187. [CrossRef]

37. Wang, Y.-J.; Xing, Z.-X.; Zhang, X.-F.; Hou, Z.-G.; Zhao, X.-S.; Dou, S.; Zhou, M.-P. On-site Detection of Volatile Organic Compounds During Composting Treatment of Livestock and Poultry Manure by GC-MS. Chin. J. Anal. Chem. 2013, 40, 899-903. [CrossRef]

38. Rincón, C.A.; De Guardia, A.; Couvert, A.; Le Roux, S.; Soutrel, I.; Daumoin, M.; Benoist, J.C. Chemical and odor charac-terization of gas emissions released during composting of solid wastes and digestates. J. Environ. Manag. 2019, 233, 39-53. [CrossRef] [PubMed]

39. Kumar, A.; Alaimo, C.P.; Horowitz, R.; Mitloehner, F.M.; Kleeman, M.J.; Green, P.G. Volatile organic compound emissions from green waste composting: Characterization and ozone formation. Atmos. Environ. 2011, 45, 1841-1848. [CrossRef]

40. González, D.; Colón, J.; Sánchez, A.; Gabriel, D. A systematic study on the VOCs characterization and odour emissions in a full-scale sewage sludge composting plant. J. Hazard. Mater. 2019, 373, 733-740. [CrossRef]

41. Goldstein, N. Getting to know the odor compounds. Biocycle 2002, 43, 42-44.

42. Nag, M.; Shimaoka, T.; Komiya, T. Nitrous oxide production during nitrification from organic solid waste under tempera-ture and oxygen conditions. Environ. Technol. 2016, 37, 2890-2897. [CrossRef]

43. Hellebrand, H.J. Emission of Nitrous Oxide and other Trace Gases during Composting of Grass and Green Waste. J. Agric. Eng. Res. 1998, 69, 365-375. [CrossRef]

44. Amlinger, F.; Peyr, S.; Cuhls, C. Greenhouse gas emissions from composting and mechanical biological treatment. Waste Manag. Res. 2008, 26, 47-60. [CrossRef] [PubMed]

45. González, D.; Guerra, N.; Colón, J.; Gabriel, D.; Ponsa, S.; Sánchez, A. Characterization of the Gaseous and Odour Emissions from the Composting of Conventional Sewage Sludge. Atmosphere 2020, 11, 211. [CrossRef] 
46. Pan, J.; Cai, H.; Zhang, Z.; Liu, H.; Li, R.; Mao, H.; Awasthi, M.K.; Wang, Q.; Zhai, L. Comparative evaluation of the use of acidic additives on sewage sludge composting quality improvement, nitrogen conservation, and greenhouse gas reduction. Bioresour. Technol. 2018, 270, 467-475. [CrossRef]

47. Yuan, J.; Chadwick, D.; Zhang, D.; Li, G.; Chen, S.; Luo, W.; Du, L.; He, S.; Peng, S. Effects of aeration rate on maturity and gaseous emissions during sewage sludge composting. Waste Manag. 2016, 56, 403-410. [CrossRef]

48. Lou, X.F.; Nair, J. The impact of landfilling and composting on greenhouse gas emissions-A review. Bioresour. Technol. 2009, 100, 3792-3798. [CrossRef]

49. Banar, M.; Cokaygil, Z.; Ozkan, A. Life cycle assessment of solid waste management options for Eskisehir, Turkey. Waste Manag. 2009, 29, 54-62. [CrossRef] [PubMed]

50. Güereca, L.P.; Gassó, S.; Baldasano, J.M.; Jiménez-Guerrero, P. Life cycle assessment of two biowaste management systems for Barcelona, Spain. Resour. Conserv. Recycl. 2006, 49, 32-48. [CrossRef]

51. Yay, A.S.E. Application of life cycle assessment (LCA) for municipal solid waste management: A case study of Sakarya. J. Clean. Prod. 2015, 94, 284-293. [CrossRef]

52. Komakech, A.J.; Sundberg, C.; Jönsson, H.; Vinnerås, B. Life cycle assessment of biodegradable waste treatment systems for sub-Saharan African cities. Resour. Conserv. Recycl. 2015, 99, 100-110. [CrossRef]

53. Bohacz, J. Changes in mineral forms of nitrogen and sulfur and enzymatic activities during composting of lignocellulosic waste and chicken feathers. Environ. Sci. Pollut. Res. 2019, 26, 10333-10342. [CrossRef]

54. Zhu, P.; Shen, Y.; Pan, X.; Dong, B.; Zhou, J.; Zhang, W.; Li, X. Reducing odor emissions from feces aerobic composting: Additives. RSC Adv. 2021, 11, 15977-15988. [CrossRef]

55. Liang, Y.; Leonard, J.J.; Feddes, J.J.; McGill, W.B. A SIMULATION MODEL OF AMMONIA VOLATILIZATION IN COMPOSTING. Trans. ASAE 2004, 47, 1667-1680. [CrossRef]

56. Wang, Y.; Liu, S.J.; Xue, W.T.; Guo, H.; Li, X.R.; Zuo, G.Y.; Zhao, T.K.; Dong, H.M. The Characteristics of Carbon, Ni-trogen and Sulfur Transformation During Cattle Manure Composting-Based on Different Aeration Strategies. Int. J. Environ. Res. Public Health. 2019, 16, 3930. [CrossRef] [PubMed]

57. Chen, J.; Chen, T.-B.; Gao, D.; Lei, M.; Zheng, G.-D.; Liu, H.-T.; Guo, S.-L.; Cai, L. Reducing $\mathrm{H}_{2} \mathrm{~S}$ production by $\mathrm{O}_{2}$ feedback control during large-scale sewage sludge composting. Waste Manag. 2011, 31, 65-70. [CrossRef] [PubMed]

58. Amon, B.; Amon, T.; Boxberger, J.; Alt, C. Emissions of $\mathrm{NH}_{3}, \mathrm{~N}_{2} \mathrm{O}$ and $\mathrm{CH}_{4}$ from dairy cows housed in a farmyard manure tying stall (housing, manure storage, manure spreading). Nutr. Cycl. Agroecosyst. 2001, 60, 103-113. [CrossRef]

59. Fillingham, M.A.; VanderZaag, A.C.; Burtt, S.; Balde, H.; Ngwabie, N.M.; Smith, W.; Hakami, A.; Wagner-Riddle, C.; Bittman, S.; MacDonald, D. Greenhouse gas and ammonia emissions from production of compost bedding on a dairy farm. Waste Manag. 2017, 70, 45-52. [CrossRef] [PubMed]

60. Guest, G.; Smith, W.; Grant, B.; VanderZaag, A.; Desjardins, R.; McConkey, B. A comparative life cycle assessment high-lighting the trade-offs of a liquid manure separatorcomposter in a Canadian dairy farm system. J. Clean. Prod. 2017, 143, 824-835. [CrossRef]

61. Ahn, H.K.; Mulbry, W.; White, J.W.; Kondrad, S.L. Pile mixing increases greenhouse gas emissions during composting of dairy manure. Bioresour. Technol. 2011, 102, 2904-2909. [CrossRef] [PubMed]

62. Arriaga, H.; Viguria, M.; López, D.M.; Merino, P. Ammonia and greenhouse gases losses from mechanically turned cattle manure windrows: A regional composting network. J. Environ. Manag. 2017, 203, 557-563. [CrossRef]

63. El Kader, N.A.; Robin, P.; Paillat, J.-M.; Leterme, P. Turning, compacting and the addition of water as factors affecting gaseous emissions in farm manure composting. Bioresour. Technol. 2007, 98, 2619-2628. [CrossRef]

64. Hao, X.; Chang, C.; Larney, F.J.; Travis, G.R. Greenhouse Gas Emissions during Cattle Feedlot Manure Composting. J. Environ. Qual. 2001, 30, 376-386. [CrossRef] [PubMed]

65. He, Y.; Inamori, Y.; Mizuochi, M.; Kong, H.; Iwami, N.; Sun, T. Nitrous Oxide Emissions from Aerated Composting of Organic Waste. Environ. Sci. Technol. 2001, 35, 2347-2351. [CrossRef]

66. Burgin, A.J.; Groffman, P.M. Soil $\mathrm{O}_{2}$ controls denitrification rates and $\mathrm{N}_{2} \mathrm{O}$ yield in a riparian wetland. J. Geophys. Res Biogeosci. 2012, 117. [CrossRef]

67. Morley, N.; Baggs, E.M.; Dörsch, P.; Bakken, L. Production of $\mathrm{NO}, \mathrm{N}_{2} \mathrm{O}$ and $\mathrm{N}_{2}$ by extracted soil bacteria, regulation by $\mathrm{NO}_{2}-$ and $\mathrm{O}_{2}$ concentrations. FEMS Microbiol. Ecol. 2008, 65, 102-112. [CrossRef]

68. Saggar, S.; Jha, N.; Deslippe, J.; Bolan, N.S.; Luo, J.; Giltrap, D.L.; Kim, D.-G.; Zaman, M.; Tillman, R. Denitrification and N 2 O:N 2 production in temperate grasslands: Processes, measurements, modelling and mitigating negative impacts. Sci. Total. Environ. 2013, 465, 173-195. [CrossRef] [PubMed]

69. Parkinson, R.; Gibbs, P.; Burchett, S.; Misselbrook, T. Effect of turning regime and seasonal weather conditions on nitrogen and phosphorus losses during aerobic composting of cattle manure. Bioresour. Technol. 2004, 91, 171-178. [CrossRef]

70. Szanto, G.L.; Hamelers, H.V.M.; Rulkens, W.H.; Veeken, A.H.M. $\mathrm{NH}_{3}, \mathrm{~N}_{2} \mathrm{O}$ and $\mathrm{CH}_{4}$ emissions during passively aerated composting of straw-rich pig manure. Bioresour. Technol. 2007, 98, 2659-2670. [CrossRef]

71. Ermolaev, E.; Pell, M.; Smårs, S.; Sundberg, C.; Jönsson, H. Greenhouse gas emission from covered windrow composting with controlled ventilation. Waste Manag. Res. 2012, 30, 155-160. [CrossRef]

72. Pattey, E.; Trzcinski, M.K.; Desjardins, R.L. Quantifying the reduction of greenhouse gas emissions as a result of com-posting dairy and beef cattle manure. Nutr. Cycling Agroecosyst. 2005, 72, 173-187. [CrossRef] 
73. Sánchez-Monedero, M.A.; Serramiá, N.; Civantos, C.G.; Fernández-Hernández, A.; Roig, A. Greenhouse gas emissions during composting of two-phase olive mill wastes with different agroindustrial by-products. Chemosphere 2010, 81, 18-25. [CrossRef]

74. Yamulki, S. Effect of straw addition on nitrous oxide and methane emissions from stored farmyard manures. Agric. Ecosyst. Environ. 2006, 112, 140-145. [CrossRef]

75. Yang, F.; Li, G.; Zang, B.; Zhang, Z. The maturity and $\mathrm{CH}_{4}, \mathrm{~N}_{2} \mathrm{O}, \mathrm{NH}_{3}$ emissions from vermicomposting with agricultural waste. Compost Sci. Util. 2017, 25, 262-271. [CrossRef]

76. Qin, L.; Shen, Y.; Li, G.; Hu, J. C matter change of composting with different C/N. J. Agro-Environ. Sci. 2010, 29, $1388-1393$.

77. González, D.G.; Colón, J.; Gabriel, D.; Sánchez, A. The effect of the composting time on the gaseous emissions and the compost stability in a full-scale sewage sludge composting plant. Sci. Total. Environ. 2019, 654, 311-323. [CrossRef]

78. Xie, J.; Li, Y.; Dong, H.; Huang, H.; Yu, Q. 2003 Influence of different factors on greenhouse gas emissions in composting of layer-hen manure with closed composting bins. Trans. Chin. Soc. Agric. Eng. 2003, 19, 192-195.

79. Hwang, S.; Hanaki, K. Effects of oxygen concentration and moisture content of refuse on nitrification, denitrification and nitrous oxide production. Bioresour. Technol. 2000, 71, 159-165. [CrossRef]

80. Yan, Y.; Wang, D.; Zheng, J. Advances in effects of biochar on the soil $\mathrm{N}_{2} \mathrm{O}$ and $\mathrm{CH}_{4}$ emissions. Chin. Agric. Sci. Bull. 2013, 29, 140-146.

81. Hao, S. Process of Windrow and Trough Type Composting in Cold Region. Master's Thesis, Heilongjiang Bayi Agricultural University, Daqing, China, 2011.

82. Tsutsui, H.; Fujiwara, T.; Matsukawa, K.; Funamizu, N. Nitrous oxide emission mechanisms during intermittently aerated composting of cattle manure. Bioresour. Technol. 2013, 141, 205-211. [CrossRef]

83. Huang, G.F.; Wong, J.W.C.; Wu, Q.T.; Nagar, B.B. Effect of $\mathrm{C} / \mathrm{N}$ on composting of pig manure with sawdust. Waste Manag. 2004, 24, 805-813. [CrossRef]

84. Pagans, E.; Font, X.; Sanchez, A. Emission of volatile organic compounds from composting of different solid wastes: Abatement by biofiltration. J. Hazard. Mater. 2006, 131, 179-186. [CrossRef]

85. Tong, B.; Wang, X.; Wang, S.; Ma, L.; Ma, W. Transformation of nitrogen and carbon during composting of manure litter with different methods. Bioresour. Technol. 2019, 293, 122046. [CrossRef] [PubMed]

86. He, P.; Wei, S.; Shao, L.; Lü, F. Emission potential of volatile sulfur compounds (VSCs) and ammonia from sludge compost with different bio-stability under various oxygen levels. Waste Manag. 2017, 73, 113-122. [CrossRef] [PubMed]

87. Jiang, T.; Schuchardt, F.; Li, G.; Guo, R.; Zhao, Y. Effect of C/N ratio, aeration rate and moisture content on ammonia and greenhouse gas emission during the composting. J. Environ. Sci. 2011, 23, 1754-1760. [CrossRef]

88. Rosenfeld, P.; Grey, M.; Sellew, P. 2004 Measurement of biosolids compost odor emissions from a windrow, static pile, and biofilter. Water Environ. Res. 2004, 76, 310-315. [CrossRef]

89. Quiros, D.C.; Yoon, S.; Dwyer, H.A.; Collins, J.F.; Zhu, Y.; Huai, T. Measuring particulate matter emissions during parked active diesel particulate filter regeneration of heavy-duty diesel trucks. J. Aerosol Sci. 2014, 73, 48-62. [CrossRef]

90. Chowdhury, M.A.; de Neergaard, A.; Jensen, L.S. Potential of aeration flow rate and bio-char addition to reduce greenhouse gas and ammonia emissions during manure composting. Chemosphere 2014, 97, 16-25. [CrossRef] [PubMed]

91. Gao, M.C.; Li, B.; Yu, A.; Liang, F.; Yang, L.; Sun, Y. The effect of aeration rate on forced-aeration composting of chicken manure and sawdust. Bioresour. Technol. 2010, 101, 1899-1903. [CrossRef] [PubMed]

92. Talib, A.T.; Mokhtar, M.N.; Baharuddin, A.S.; Sulaiman, A. Effects of aeration rate on degradation process of oil palm empty fruit bunch with kinetic-dynamic modeling. Bioresour. Technol. 2014, 169, 428-438. [CrossRef]

93. Zhang, J.; Sui, Q.; Li, K.; Chen, M.; Tong, J.; Qi, L.; Wei, Y. Influence of natural zeolite and nitrification inhibitor on organics degradation and nitrogen transformation during sludge composting. Environ. Sci. Pollut. Res. 2017, 24, 9122. [CrossRef]

94. Wang, X.; Selvam, A.; Chan, M.; Wong, J.W.C. Nitrogen conservation and acidity control during food wastes com-posting through struvite formation. Bioresour. Technol. 2013, 147, 17-22. [CrossRef]

95. Lim, S.L.; Lee, L.H.; Wu, T.Y. Sustainability of using composting and vermicomposting technologies for organic solid waste biotransformation: Recent overview, greenhouse gases emissions and economic analysis. J. Clean. Prod. 2016, 111, 262-278. [CrossRef]

96. Jolanun, B.; Towprayoon, S. Novel bulking agent from clay residue for food waste composting. Bioresour. Technol. 2010, 101, 4484-4490. [CrossRef]

97. Iqbal, M.K.; Shafiq, T.; Ahmed, K. Characterization of bulking agents and its effects on physical properties of compost. Bioresour. Technol. 2010, 101, 1913-1919. [CrossRef] [PubMed]

98. Gu, W.J.; Sun, W.; Lu, Y.S.; Li, X.; Xu, P.Z.; Xie, K.Z.; Sun, L.L.; Wu, H.T. Effect of Thiobacillus thioparus 1904 and sulphur addition on odour emission during aerobic composting. Bioresour. Technol. 2018, 249, 254-260. [CrossRef]

99. Barrington, S.; Choinière, D.; Trigui, M.; Knight, W. Compost convective airflow under passive aeration. Bioresour. Technol. 2003, 86, 259-266. [CrossRef]

100. Li, S.; Huang, G.-H.; An, C.-J.; Yu, H. Effect of different buffer agents on in-vessel composting of food waste: Performance analysis and comparative study. J. Environ. Sci. Heal. Part. A 2013, 48, 772-780. [CrossRef] [PubMed]

101. Chadwick, D.R. Emissions of ammonia, nitrous oxide and methane from cattle manure heaps: Effect of compaction and covering. Atmos. Environ. 2005, 39, 787-799. [CrossRef] 
102. Chowdhury, M.A.; de Neergaard, A.; Jensen, L.S. Composting of solids separated from anaerobically digested animal manure: Effect of different bulking agents and mixing ratios on emissions of greenhouse gases and ammonia. Biosys. Eng. 2014, $124,63-77$. [CrossRef]

103. Steiner, C.; Das, K.C.; Melear, N.; Lakly, D. Reducing Nitrogen Loss during Poultry Litter Composting Using Biochar. J. Environ. Qual. 2010, 39, 1236-1242. [CrossRef]

104. Al-Jabi, L.F.; Halalsheh, M.M.; Badarneh, D.M. Conservation of ammonia during food waste composting. Environ. Technol. 2008, 29, 1067-1073. [CrossRef]

105. Zeng, Y.; De Guardia, A.; Dabert, P. Imporve composting as a post-treatment of anaerobic digestate. Bioresour. Technol. 2016, 201, 293-303. [CrossRef]

106. Chen, W.; Yan, L.; Gao, Y.; Bao, J.; Wang, Y.; Sun, Z.; Wang, W. The removal characteristics and diversity of a microbial community capable of ammonia removal from compost. Ann. Microbiol. 2016, 66, 635-642. [CrossRef]

107. Shan, J.; Shao, X. Nitrogen preserving and deodorizing technology in high temperature composting of cow manure. Environ. Sci. Technol. 2008, 31, 47-50.

108. Chan, Y.C.; Sinha, R.K.; Wang, W.J. Emission of greenhouse gases from home aerobic composting, anaerobic digestion and vermicomposting of household wastes in Brisbane (Australia). Waste Manag. Res. 2010, 29, 540-548. [CrossRef]

109. Chen, R.; Wang, Y.; Wang, W.; Wei, S.; Jing, Z.; Lin, X. $\mathrm{N}_{2} \mathrm{O}$ emissions and nitrogen transformation during windrow com-posting of dairy manure. J. Environ. Manag. 2015, 160, 121-127. [CrossRef]

110. Robin, P.; Germain, P.; Lecomte, M.; Landrain, B.; Li, Y.; Cluzeau, D. Earthworm effects on gaseous emissions during vermifiltration of pig fresh slurry. Bioresour. Technol. 2011, 102, 3679-3686.

111. Velasco-Velasco, J.; Parkinson, R.; Kuri, V. Ammonia emissions during vermicomposting of sheep manure. Bioresour. Technol. 2011, 102, 10959-10964. [CrossRef] [PubMed]

112. Wang, J.; Hu, Z.; Xu, X.; Jiang, X.; Zheng, B.; Liu, X.; Pan, X.; Kardol, P. Emissions of ammonia and greenhouse gases during combined pre-composting and vermicomposting of duck manure. Waste Manag. 2014, 34, 1546-1552. [CrossRef]

113. Liu, B.; Mørkved, P.T.; Frostegård, A.; Bakken, L.R. Denitrification gene pools, transcription and kinetics of $\mathrm{NO}_{2} \mathrm{~N}_{2} \mathrm{O}$ and $\mathrm{N}_{2}$ production as affected by soil pH. FEMS Microbiol. Ecol. 2010, 72, 407-417. [CrossRef] [PubMed]

114. Tubail, K.; Chen, L.; Michel, F.C., Jr.; Keener, H.M.; Rigot, J.F.; Klingman, M.; Kost, D.; Dick, W.A. Gypsum additions reduce ammonia nitrogen losses during composting of dairy manure and biosolids. Compost Sci. Util. 2008, 16, 285-293. [CrossRef]

115. Wang, Q.; Wang, Z.; Awasthi, M.K.; Jiang, Y.; Li, R.; Ren, X.; Zhao, J.; Shen, F.; Wang, M.; Zhang, Z. Evaluation of medical stone amendment for the reduction of nitrogen loss and bioavailability of heavy metals during pig manure composting. Bioresour. Technol. 2016, 220, 297-304. [CrossRef] [PubMed]

116. Hou, Y.; Velthof, G.L.; Oenema, O. Mitigation of ammonia, nitrous oxide and methane emissions from manure management chains: A meta-analysis and integrated assessment. Glob. Chang. Biol. 2015, 21, 1293-1312. [CrossRef]

117. Ti, C.; Xia, L.; Chang, S.X.; Yan, X. Potential for mitigating global agricultural ammonia emission: A meta-analysis. Environ. Pollut. 2019, 245, 141-148. [CrossRef]

118. Cao, Y.; Wang, X.; Liu, L.; Velthof, G.L.; Misselbrook, T.; Bai, Z.; Ma, L. Acidification of manure reduces gaseous emissions and nutrient losses from subsequent composting process. J. Environ. Manag. 2020, 264, 110454. [CrossRef] [PubMed]

119. Li, Y.; Luo, W.; Li, G.; Wang, K.; Gong, X. Performance of phosphogypsum and calcium magnesium phosphate fertilizer for nitrogen conservation in pig manure composting. Bioresour. Technol. 2018, 250, 53-59. [CrossRef]

120. Liu, Y.; Ma, R.; Li, D.; Qi, C.; Han, L.; Chen, M.; Fu, F.; Yuan, J.; Li, G. Effects of calcium magnesium phosphate fertilizer, biochar and spent mushroom substrate on compost maturity and gaseous emissions during pig manure composting. J. Environ. Manag. 2020, 267, 110649. [CrossRef] [PubMed]

121. Jiang, T.; Ma, X.; Tang, Q.; Yang, J.; Li, G.; Schuchardt, F. Combined use of nitrification inhibitor and struvite crystallization to reduce the $\mathrm{NH}_{3}$ and $\mathrm{N}_{2} \mathrm{O}$ emissions during composting. Bioresour. Technol. 2016, 217, 210-218. [CrossRef] [PubMed]

122. Chan, M.T.; Selvam, A.; Wong, J.W. Reducing nitrogen loss and salinity during 'struvite' food waste composting by zeolite amendment. Bioresour. Technol. 2016, 200, 838-844. [CrossRef]

123. Jungbluth, T.; Hartung, E.; Brose, G. Greenhouse gas emissions from animal houses and manure stores. Nutr. Cycl. Agroecosystems 2001, 60, 133-145. [CrossRef]

124. Huang, G.; Fang, C.; Ma, S.; Han, L. Storage stability of micro-aerobic coupling functional membrane and gas emission reduction of dairy manure. Trans. Chin. Soc. Agric. Mach. 2018, 49, 335-341.

125. Zhu, X.; Dong, W.; Wang, H.; Yan, C.; Liu, H.; Liu, E. Effects of cattle manure composting methods on greenhouse gas and ammonia emissions. Trans. Chin. Soc. Agric. Eng. 2017, 33, 258-264.

126. Madrini, B.; Shibusawa, S.; Kojima, Y.; Hosaka, S. Effect of natural zeolite (clinoptilolite) on ammonia emissions of leftover food-rice hulls composting at the initial stage of the thermophilic process. J. Agric. Meteorol. 2016, 72, 12-19. [CrossRef]

127. Villaseñor, J.; Rodríguez, L.; Fernández, F.J. Composting domestic sewage sludge with natural zeolites in a rotary drum reactor. Bioresour. Technol. 2011, 102, 1447-1454. [CrossRef]

128. Turan, N.G. Nitrogen availability in composted poultry litter using natural amendments. Waste Manag. Res. 2009, $27,19-24$. [CrossRef] [PubMed]

129. Hong, J.H.; Park, K.J. Compost biofiltration of ammonia gas from bin composting. Bioresour. Technol. 2005, 96, 741-745. [CrossRef] 
130. Clemens, J.; Cuhls, C. Greenhouse gas emissions from mechanical and biological waste treatment of municipal waste. Environ. Technol. 2003, 24, 745-754. [CrossRef]

131. Pagans, E.; Font, X.; Sánchez, A. Biofiltration for ammonia removal from composting exhaust gases. Chem. Eng. J. 2005, 113, 105-110. [CrossRef]

132. Li, Q.; Wang, X.C.; Zhang, H.H.; Shi, H.L.; Hu, T.; Ngo, H.H. Characteristics of nitrogen transformation and microbial community in an aerobic composting reactor under two typical temperatures. Bioresour. Technol. 2013, 137, 270-277. [CrossRef]

133. Liu, W.; Huo, R.; Xu, J.; Liang, S.; Li, J.; Zhao, T.; Wang, S. Effects of biochar on nitrogen transformation and heavy metals in sludge composting. Bioresour. Technol. 2017, 235, 43-49. [CrossRef]

134. Awasthi, M.K.; Wang, Q.; Huang, H.; Li, R.; Shen, F.; Lahori, A.H.; Wang, P.; Guo, D.; Guo, Z.; Jiang, S.; et al. Effect of biochar amendment on greenhouse gas emission and bio-availability of heavy metals during sewage sludge co-composting. J. Clean. Prod. 2016, 135, 829-835. [CrossRef]

135. Malińska, K.; Zabochnicka-Świątek, M.; Dach, J. Effects of biochar amendment on ammonia emission during composting of sewage sludge. Ecol. Eng. 2014, 71, 474-478. [CrossRef]

136. Agyarko-Mintah, E.; Cowie, A. Biochar increases nitrogen retention and lowers greenhouse gas emissions when added to composting poultry litter. Waste Manag. 2017, 61, 138-149. [CrossRef]

137. Sun, D.; Lan, Y.; Xu, E.G.; Meng, J.; Chen, W. Biochar as a novel niche for culturing microbial communities in composting. Waste Manag. 2016, 54, 93-100. [CrossRef]

138. Khan, N.; Clark, I.; Sánchez-Monedero, M.A.; Shea, S.; Meier, S.; Bolan, N. Maturity indices in co-composting of chicken manure and sawdust with biochar. Bioresour. Technol. 2014, 168, 245-251. [CrossRef] [PubMed]

139. Chen, W.; Liao, X.; Wu, Y.; Liang, J.B.; Mi, J.; Huang, J.; Zhang, H.; Wu, Y.; Qiao, Z.; Li, X.; et al. Effects of different types of biochar on methane and ammonia mitigation during layer manure composting. Waste Manag. 2017, 61, 506-515. [CrossRef] [PubMed]

140. Zhou, S.; Wen, X.; Cao, Z.; Cheng, R.; Qian, Y.; Mi, J.; Wang, Y.; Liao, X.; Ma, B.; Zou, Y.; et al. Modified cornstalk biochar can reduce ammonia emissions from compost by increasing the number of ammonia-oxidizing bacteria and decreasing urease activity. Bioresour. Technol. 2021, 319, 124120. [CrossRef]

141. Jia, X.; Wang, M.; Yuan, W.; Shah, S.; Shi, W.; Meng, X.; Ju, X.; Yang, B. $\mathrm{N}_{2} \mathrm{O}$ Emission and Nitrogen Transformation in Chicken Manure and Biochar Co-Composting. Trans. ASABE 2016, 59, 1277-1283. [CrossRef]

142. Guo, H.; Gu, J.; Wang, X.; Yu, J.; Nasir, M.; Zhang, K.; Sun, W. Microbial driven reduction of $\mathrm{N}_{2} \mathrm{O}$ and $\mathrm{NH}_{3}$ emissions during composting: Effects of bamboo charcoal and bamboo vinegar. J. Hazard. Mater. 2019, 390, 121292. [CrossRef]

143. Yang, Y.; Awasthi, M.K.; Wu, L.; Yan, Y.; Lv, J. Microbial driving mechanism of biochar and bean dregs on $\mathrm{NH}_{3}$ and $\mathrm{N}_{2} \mathrm{O}$ emissions during composting. Bioresour. Technol. 2020, 315, 123829. [CrossRef] 